\title{
Antarctica research essential for continued influence, says panel
}

Washington. The United States must continue its research activities in Antarctica if it wants to maintain its political influence in the region, according to a report to Congress from the National Science and Technology Council (NSTC), the body that coordinates science policy in President Bill Clinton's administration.

The report - requested by senators who have challenged the value of the $\$ 200$ million spent each year on Antarctic activities by the National Science Foundation (NSF) applauds the quality of the science being done there. But it emphasizes that the chief justification for the programme, including a year-round presence at the South Pole itself, is to secure US influence in the administration of the Antarctic Treaty.

The 1959 treaty prohibits military activity on or near the continent and imposes a moratorium on the pursuit of territorial claims, including conflicting ones between Argentina, Chile and the United Kingdom. In a memorandum attached to the NSTC report, the US State Department argues that abandoning the South Pole station would create a vacuum, whose likely result would be "a scramble to occupy the site, to the detriment of our position as well as to the stability of the Treaty system".

The memorandum argues that the programme earns the United States "a decisive role" in Antarctica under the treaty, which divides influence among the signatory nations on the basis of their actual activity on the continent.

But the NSTC falls short of recommending the construction of a new South Pole station to replace the current, rather dilapidated one until "further cost-benefit analyses" have been done. The highest priority, it says, is a \$25-million emergency repair programme, which is part of the NSF's 1997 budget proposal.

The Antarctic science programme provides vital input in the study of global systems, including continental drift, climate change and ocean circulation. The continent also serves as a unique natural laboratory because of its isolation, making it a useful platform for astronomers. And the geography itself is of great interest to oceanographers and geophysicists. But research is expensive, with logistics consuming twothirds of NSF's investment.

The panel report says that the main McMurdo station and its two outposts the Palmer station and the Amundsen-Scott station at the South Pole - should all stay open. But is also says that a new panel of logistics experts should be brought together by NSF to establish how this can be done if

IMAGE
UNAVAILABLE
FOR COPYRIGHT
REASONS

Flying the flag: but no new money for rebuilding.

funding is frozen

Neal Sullivan, head of polar programmes at the NSF, says that the report's endorsement is "critically important" to the future of the programme. But he says that he is "disappointed that we do not have the green light" to rebuild the South Pole station.
"That is the next step, and that is what we need to work towards."

Gerald Garvey, of the White House Office of Science and Technology Policy, $\rightarrow$ one of the authors of the report, says

o that the South Pole station still has

䇏 “ten or fifteen years" of useful life left. $\sum_{0}$ But Sullivan says that with a new sta-

. to build, a start must be made quickly.

The report was requested by the Senate Appropriations Committee at the suggestion of Ted Stevens (Republican, Alaska), who has a long-standing (and understandable) concern that most of NSF's polar programmes money goes to the pole which is far from his home state.

Administration officials hope that the report will at least help them make the case in Congress for the $\$ 25$ million of urgent repairs to the South Pole station. Last year, Congress cut $\$ 20$ million from the administration's request for polar programmes.

Colin Macilwain

\section{Scrutiny delays Brent Spar report}

London. Delays in the publication of a report written by a group of scientists at the invitation of the British government to evaluate the environmental implications of deep sea disposal of the Brent Spar, a disused oil storage buoy owned by the Shell oil company, has fuelled speculation that its conclusions are being viewed less than favourably by the government.

The inquiry was set up at the government's request by John Krebs, chief executive of the Natural Environment Research Council (NERC), shortly after Shell's decision to bow to public pressure and abandon plans to sink the buoy in the mid-Atlantic (see Nature $\mathbf{3 8 0}, \mathbf{1 3} ; \mathbf{1 9 9 6}$ ). Its report was submitted to Tim Eggar, minister of energy at the Department of Trade and Industry (DTI), on 3 April, and had been expected to be launched at a press conference on 24 April.

No official reasons have been given for the delay. But some sources say that Eggar - who strongly favours deep sea disposal of the buoy - is unhappy with the report's conclusions. "He expected the scientists to endorse dumping the Brent Spar in the sea," says one individual who has seen the report. "But the scientists did not say that."

A spokesman for the department acknowledges that the report has been seen by the minister, but refuses to say when it will be released. Helen Wallace, a senior scientist with Greenpeace, says the report should be published without delay. "Would they be so slow to publish a report that said exactly what they wanted?" she asks.

The group of "independent expert scientists" was set up to review the scientific, engineering and environmental aspects of deep sea disposal compared to other disposal options. But it did not have time to evaluate other options, and concentrated instead on the impact of deep-sea disposal.

One of the scientists, who did not wish to be named, confirmed that the report did not endorse deep-sea disposal as the 'best environmental option', but said that this was because such a recommendation had not been requested.

A difference of opinion is also believed to have emerged between the DTI and NERC over who should pay the costs of printing the report, and how many should be printed. The DTI is believed to favour restricted circulation of the report to a limited number of selected individuals, while NERC is said to be pushing for wider dissemination.

Ehsan Masood 